\title{
Derleme/Review \\ Entomolojide DNA Barkodlama Tekniğinin Kullanımı
}

\author{
Gökhan YATKIN ${ }^{1}$ Nurper GÜZ ${ }^{2 *}$ \\ ${ }^{1}$ Ankara Zirai Mücadele Merkez Araştırma Enstitüsü, Ankara, Türkiye \\ ${ }^{2}$ Ankara Üniversitesi Ziraat Fakültesi Bitki Koruma Bölümü, Ankara, Türkiye \\ *e-posta: nurperguz@agri.ankara.edu.tr
}

\begin{abstract}
Özet: DNA barkodlama, herhangi bir organizmaya ait DNA'nın PCR teknikleri ile çoğaltılacak büyüklükteki kısa ve standart bir fragmanının dizilenmesi ile tanılanmasını sağlayan taksonomik bir yöntem olarak ifade edilebilir. Bu amaçla böceklerle yapılan çalışmalarda 'DNA barkodu' olarak bilinen mitokondriyal sitokrom c oksidaz alt ünite I (COI) geninin yaklaşık 600-700 baz çiftine (bç) ait kısmı kullanılmaktadır. Bu kısa standart DNA sekansı türlerin tanılanmasını kolaylaştırmasının yanı sıra yeni türlerin keşfi için de oldukça iyi bir araçtır. Ayrıca DNA barkodlama türlerin sınırlarını belirleyerek kriptik türlerin ayrımına katkı sağlar. Bu derlemede DNA barkodlama teriminin tarihsel ve kavramsal olarak ortaya çıkışı, DNA barkodu olarak kullanılan gen bölgeleri ve böcekler için ideal tür tanımlama markörü olan COI gen bölgesi hakkında bilgi verilmiştir. Son olarak DNA barkodlamanın avantajları ve kısitlamaları irdelenerek entomolojide DNA barkodlama çalışmalarından örnekler sunulmuştur.
\end{abstract}

Anahtar kelimeler: COI, DNA barkodlama, Entomoloji, Taksonomi, Tür tanımlama

\section{The Use of DNA Barcoding in Entomology}

\begin{abstract}
DNA barcoding is a taxonomic method that uses a short and standard genomic DNA fragment to discriminate species. An approximately 600-700 base pair (bp) region of the mitochondrial cytochrome coxidase subunit I (COI) gene referred as 'DNA barcode' is used in insect barcoding studies. This short standart DNA sequence is not only a tool for simplifying species identification but also is used for discovery of new species. Furthermore DNA barcoding enables the detection of cryptic species via delimiting species boundaries. Here we reviewed the historical and conceptual perspective of DNA barcoding term, the gene regions used as DNA barcodes and $\mathrm{COI}$ gene which is ideal species-identification marker in insects. Furthermore we discussed the advantages and limitations of DNA barcoding and presented DNA barcoding studies in entomology.
\end{abstract}

Keywords: COI, DNA barcode, Entomology, DNA barcode, Taxonomy, Species identification

\section{Giriş}

Böcekler dünya üzerinde en fazla çeşitlilik gösteren canlılardır ve muazzam şekilde farklı form aralıklarında evrimleşme gösterirler. Sadece türlerin \%10'unun tanımlanması taksonomistlerin neredeyse 200 yılını almıştır ve halen tanımlanmayı bekleyen çok sayıda böcek türü bulunmaktadır (Jalali ve ark. 2015). Tür tanımlama, biyoçeşitliliği tanımanın ve tanımlamanın temel bir parçasıdır. Ekoloji, evrim biyolojisi ve tarım alanlarında biyoçeşitliliğe ilginin artmasıyla birlikte türlerin güvenilir teşhisi giderek önem kazanmıştır. Geleneksel olarak tür tanımlama morfolojik teşhislere dayanmaktadır. Teşhis ve tanımlama işlemi yalnızca morfolojik verilere dayandırıldığında, etkin bir tanımlama sadece taksonomistler ve eğitimli uzmanlar tarafından gerçekleştirilebilmektedir. Ancak taksonomistlerin ve diğer tanımlama uzmanlarının sayısı giderek azalmaktadır (Page 2016). Son yillarda DNA dizileme teknolojilerindeki gelişmelerle birlikte türlerin doğru, hızlı ve kolayca tanılanması mümkün olabilmektedir. DNA temelli taksonomi yöntemi olarak bilinen DNA barkodlama günümüzde türlerin tanılanmasında ve yeni türlerin keşfinde yaygın olarak kullanılmaktadır (Hajibabaei ve ark. 2016).

\section{DNA Barkodlama Terimi ve Kullanılan Gen Bölgeleri}

DNA barkodlama genomik DNA'nın kısa ve standart bir fragmanının kullanılarak organizmaların tanılanmasını sağlayan taksonomik bir yöntem olarak ifade edilebilir. Elde edilen standart DNA dizisine DNA barkodu denir. DNA barkodu terimi ilk defa 1993 yılında Arnot ve ark. tarafından kullanılmıştır. Aslında moleküler yöntemlerin 
kullanılarak türlerin tanılanması kavramı Sanger dizileme tekniğinin (Sanger ve ark. 1977) keşfinden de eskiye dayanmaktadır. Ancak 2003 yılında bu konuda peş peşe çıkan yayınlar ile DNA barkodlamanın altın çağı başlamıştır. Hebert ve ark. (2003 a, b) çok sayıda biyolojik örneğin hızlı ve güvenilir tanılanması için mitokondriyal sitokrom-c oksidaz alt birim 1 (COI) geninin yaklaşık 650 baz çiftlik (bp) bölgesini çoğaltan DNA barkodlama tekniğini önermiştir. 2004 yllında türlerin DNA barkodlanmasında standart bir protokol oluşturulması ve geniş kapsamlı DNA barkod kütüphanesinin oluşturulması amacıyla 'Yaşamın Barkodlanması Konsorsiyumu' (Consortium for the Barcode of Life "CBOL") kurulmuştur. Ardından tüm ökaryotların DNA barkod kütüphanesini otomatik olarak tanımlanmasını hedef alan "Uluslararası Yaşamın Barkodlanması" adı altında 26 ülkenin katılımıyla bir işbirliği başlatılmıştır (iBOL; International Barcode of Life 2010).

DNA barkodlama tekniğinde her türün kendine özgü nükleotid dizilimini ortaya çıkarmak için türün genomu değil, sadece bir ya da birkaç gen bölgesinin dizilimindeki farklılık/benzelikler temel alınır. DNA barkodlama için yaygın olarak kullanılan gen bölgeleri, nükleer DNA (ITS), kloroplast DNA (RbcL, trnL-F, matK, psbA, $\operatorname{trnH}, p s b K)$ ve mitokondriyal DNA (COI)'dır. Standart DNA barkod bölgesi olan COI bölgesi bir mitokondriyal gendir ve tür tanımlaması için çok etkilidir. Bu bölge, çoğu hayvan grubu için iyi ayırt etme gücüne sahiptir, bu nedenle COI geni Uluslararası Yaşam Barkodu Proje ekibi tarafindan hayvanlar için resmi barkod markörü olarak tanımlamıştır (Hebert ve ark. 2003a). COI gen bölgesi entomoloji çalışmalarında da yaygın bir şekilde ideal tür tanımlama markörü olarak kullanılmaktadır.

\section{Neden COI İdeal Bir Barkodlama Genidir?}

Mitokondriyal genom introndan yoksun, haploit yapıda sınırlı rekombinasyon sergilemesi ve maternal kalıtıma sahip olması nedeniyle nükleer genoma kıyasla DNA barkodlama çalışmalarında daha çok tercih edilir. Ayrıca, her hücrede birkaç mitokondri ve her bir mitokondride nispeten bol miktarda DNA kopyası bulunmaktadır (1 ila 1000 kopya). Bu nedenle, çalışılacak doku örneği sınırlı olsa bile, başarılı bir PCR için yeterli miktarda mitokondriyal DNA elde etmek mümkündür (Hebert ve ark. 2003a; Blaxter 2004).

Hayvan mitokondri genomunda bulunan on üç protein kodlayıcı gen arasından COI geni ideal bir barkod markörü olarak iki nedenden dolayı önerilmiştir (Hebert ve ark. 2003a). Bunlardan ilki COI genine ait üniversal primerlerin oldukça stabil olması, ikincisi ise nükleotid substitüsyon oranının yakın ilişkili türleri ve aynı türdeki farklı popülasyonları da ayırmaya yetecek kadar yüksek olmasıdır. COI geni, aynı türe ait bireyleri tanımlamak için kullanılabildiği gibi farklı türlerden bireyleri ayırt etmek için de kullanılabilir. Bunun nedeni, gen dizisinin evrimsel içerisinde değişme oranıdır. Bu oran aynı türde yeterince yavaş fakat farklı türler arasındaki farklılaşma için yeterince hızlıdır (Rach ve ark. 2017). İdeal bir barkod markörünün amplifikasyonu ve hizalanması da kolay olmalıdır. Dolayısıyla COI geni bu bakımdan da son derece uygundur.

\section{DNA Barkodlamanin Avantajları}

DNA barkodlamanın diğer moleküler yöntemlere (RAPD, RFLP, AFLP vb.) göre birçok avantaj1 vardır. Bunlardan en önemlisi DNA barkodlama tekniğinin evrensel olmasıdır. Daha önce kullanılan moleküler yöntemler, ilgili taksonomik grubun farklı DNA bölgelerine uyarlanmıştır. Bu nedenle bu metotlar için kullanılan primerler ve protokoller sadece sınırlı sayıda ve spesifik organizmalar için uygulanabilmektedir. Ancak standart DNA barkodlama teknolojisinde kullanılan primer seti (Folmer ve ark. 1994) pek çok hayvan türüne ait olan COI geninin kısa bir fragmanının çoğaltılmasına yöneliktir.

Standart DNA barkod bölgesi olan COI, tür tanımlaması için çok etkilidir. COI gen bölgesinden elde edilen dizilerin hizalanması zor değildir, çünkü $C O I$ geni aynı zamanda protein kodlayan genler arasındadır. Dolayısıyla DNA dizileme hataları, elde edilen dizinin proteine transle olup olmadığının kontrol edilmesiyle kolayca tespit edilebilir.

DNA barkodlama, uzman olmayan ve özellikle rutin olarak çok sayıda numuneyi tanımlayan kişiler için basit ve güçlü bir yöntem olarak karşımıza çıkmaktadır. DNA barkoduna dayalı yapılan tanımlamanın güvenilirliği voucher numunelerinin doğrulanması ile artmaktadır.

DNA barkodlamanın tartışmasız bir avantajı, moleküler verilerin hızlı bir şekilde edinilmesidir. Morfolojik verileri elde etmek genellikle zaman alır iken DNA barkodlama zaman ve maliyet etkinliği nedeniyle, hızlı ve otomatik tür tanımlamasına olanak verebilmektedir (Hebert ve ark. 2003a). DNA barkodlamanın bir diğer belirgin avantajı, tür tanımlamasının moleküler temelli olması gerektiği durumlarda ortaya çıkmaktadır. $\mathrm{Bu}$ yöntem özellikle ergin döneme ulaşmamış örneklerin tanımlanmasının zor olduğu zamanda oldukça avantajlıdır (Ahrens ve ark. 2007; Hebert ve ark. 2004). Benzer şekilde böceğin bir parçasına dayalı tanımlama ya da hasar 
görmüş organizmalardan yapılacak tanımlama için DNA barkodlamanın avantajlı olduğu bildirilmiştir (Pons 2006). DNA barkodlamanın etkinliği, yeni kriptik türlerin (Gomez ve ark. 2007, Pfenninger ve ark. 2007) ve sibling türlerin tanımlanması (Hogg ve Hebert 2004; Amaral ve ark. 2007) açısından ayrıca avantaj sağlamaktadır.

\section{DNA Barkodlamanin Dezavantajları}

Referans olarak kullanılan barkod kütüphanelerinde ilgili türe ait verilerin bulunmaması ya da yanlıș tanımlanmış verilerin bulunması türlerin tanılanmasını sınırlayan önemli faktörler arasında sayılabilir. Günümüzde yapılan yanlış tanımlamaların büyük çoğunluğu referans verilerin olmamasından kaynaklanmaktadır (Virgilio ve ark. 2010). Öte yandan voucher numunelerinin yeniden tanımlanması ile yanlış tanımlamanın önlenebileceği düşünülmektedir.

Nitekim CBOL ve NCBI veri tabanlarının barkod dizileri için voucher numunelerine ait bilgilerin de yer aldığ standart veri girişi formatları mevcuttur. Her ne kadar gen bankasında referans dizilerin bulunmaması dezavantaj gibi değerlendirilse de yeni türlerin tanılanmasına ve yeni barkodların veri tabanına kazandırılmasına olanak verdiği tartışmasızdır. Benzer şekilde moleküler ve morfolojik yöntemlerin örtüşmediği durumda ortaya çıkabilecek karmaşa, ilgili örneklerin taksonomik revizyonu ile giderilebilir (Funk ve Omland 2003; Meyer ve Paulay 2005; Kehlmaier ve Assmann 2010).

Böcek örneklerinin uygun koşullarda saklanmadığı durumda DNA'nın yıkıma uğraması ile DNA fragmanlarının amplifikasyonunda zorluk söz konusu olabilmektedir. Öte yandan Thomsen ve ark. (2009) 10000 yıldan daha fazla bir süreden beri saklanan Coleoptera takımına ait fosil örneklerinden DNA izolasyonu ve ardından PCR amplifikasyonunu başarı ile gerçekleştirmiştir. Günümüzde uygun koşullarda saklanmayan örnekler, kuru örnekler ve hatta müze örnekleri için oldukça etkili DNA izolasyon yöntemleri ve DNA polymeraz enzimleri geliştirilmiştir. Ayrıca bu tür problemlerin çözümü için kısa DNA fragmanlarının kullanımı (Hajibabaei ve ark. 2006) ya da iki kısa DNA fragmanının çoğaltılıp birleştirilerek analiz edilmesi önerilmiştir (Van Houdt ve ark. 2010).

Son olarak mitokondri genomunda bulunan barkod dizilerine çok benzeyen nükleer pseudogenler (NUMT) ya da tek bir bireyde birden fazla mitokondriyel haplotiplerin bulunması olarak tanımlanan 'heteroplazmi' DNA barkodlamasının validasyonunu sınırlayan faktörler olarak sayılabilir. Ancak son yıllarda her iki faktörün etkisini azaltan analiz yöntemleri geliştirilmiştir. Moulton ve ark. (2010) NUMT'ların amplifikasyonunu azaltan COI genine spesifik primer setleri geliştirmiştir. Öte yandan heteroplazmi yoğunluğunun böceğin değişik dokularında farklılık gösterdiği saptanmıştır. Bu problemin giderilmesine yönelik yapılan bir çalışma ile abdomenden yapılacak DNA ekstraksiyonunun heteroplazmiyi azalttığı ortaya konmuştur (Magnacca ve Brown 2010).

\section{Entomolojide DNA Barkodlama Çalışmaları}

Moleküler veriler farklı gelişme dönemine sahip ya da cinsel dimorfizm gösteren aynı türün morfolojik olarak farklılık gösteren bireylerini ayırmaya yardımcı olur (Miller ve ark. 2005; Ahrens ve ark. 2007; Sutou ve ark. 2007; Gattolliat and Monaghan 2010; Hayashi ve Sota 2010; Kathirithamby ve ark. 2010; Murría ve ark. 2010; Pauls ve ark. 2010). Nymphalidae familyasına ait kelebeklerin revize edildiği bir çalışmada morfolojik özellikler ve DNA barkod verilerinin kombine edilmesiyle Caeruleuptychia trembathi olarak isimlendirilen yeni bir tür tespit edilmiştir (Nakahara ve ark. 2017). Çalışmada araştırıcıları şaşırtan, tanımladıkları yeni türde çarpıcı bir şekilde cinsel dimorfizm gösteren mavi kanatlara sahip erkekler ile kahverengi kanatlı dişi kelebeklerin DNA barkodlarının aynı türü işaret etmesi olmuştur.

Son yirmi yıldır doğadaki tritrofik ilişkiler araştırıcıların hep ilgi odağı olmuştur ve bu konunun moleküler teknikler kullanılarak araştırıldığı çok sayıda çalışma yayınlanmıştır (Asahida ve ark. 1997; Kohn ve Wayne 1997; Zaidi ve ark. 1999; Farrell ve ark. 2000; Gariepy ve ark. 2007; Matheson ve ark. 2007; Dunshea 2009; Weber ve Lundgren 2009; Sheppard ve Harwood 2005; Fournier ve ark. 2008; King ve ark. 2010). Herbivor böceklere rutinde uygulanabilecek DNA barkodlama tekniğinin böcek-konukçu bitki ilişkilerindeki ekolojik ve evrimsel bağlantıları güvenilir bir şekilde çözebileceğine inanılmaktadır. Avusturalya'da Chrysomelinae alt familyasına ait türlerin konukçu bitki özelleşmesinin araştırıldığı bir çalışmada konukçu bitkiye ait DNA barkodlarının Coleopter türlerinde aranması sonucunda zararlıya ait daha önce hiç rapor edilmemiş yeni konukçu dizilerine rastlanmıştır (Jurado-Rivera ve ark. 2009).

İngiltere'de yapılan başka bir çalışmada Adalia bipunctata ve Adalia decempunctata popülasyonlarının azalmasında birlik içi avcılığın (intraguild predation) etkili olduğu belirtilmiştir (Thomas ve ark. 2013). COI ve 
ITS1 genlerine spesifik primerler tasarlanarak yapılan PCR analizleri sonucunda istilacı Coccinellid türü olan Harmonia axyridis'in mide içeriklerinde her iki Adalia türüne rastlanmıştır. Yapılan çalışmalar Neoseilus californicus'un Tetranychus urticae bulamadığında Phytoseilus persimilis tükettiğini ortaya koymuştur (Çakmak ve ark. 2006). Benzer şekilde Orius majusculus'un Bemisia tabaci'nin yanı sıra Encarsia formosa ile parazitlenmiş beyazsinek nimflerini de tükettiği saptanmıştır (Sohrabi ve ark. 2013). Aynı çalışmada parazitlenmiş beyaz sineklerin opak hale geldiği için predatörlerin daha fazla dikkatini çektiği saptanmıştır. Birlik içi avcılığın ortaya konulduğu çok sayıda çalışmaya rastlamak mümkündür, ancak bu ilişkinin biyolojik mücadeleye olumsuz etkisinin rasyonel olarak ortaya konulması günümüzde DNA barkodlama tekniği ile güvenilir olarak yapılabilmektedir.

Biyolojik mücadelenin başarısını etkileyen başka bir faktör parazitlenme oranıdır. Özellikle larva parazitoitlerinin parazitlenme oranının belirlenmesi parazitlenmiş konukçunun laboratuvar koşullarında yetiştirilerek parazitoit çıkışının gözlenmesini gerektirir. Bunun yerine daha pratik olarak DNA barkodlarından yararlanılarak spesifik PCR amplifikasyonu ile parazitlenme oranının belirlenmesi mümkündür. Cydia pomonella'nın parazitoitlerinin geleneksel ve moleküler yöntemlerle parazitlenme oranının tespit edildiği çalışmada, moleküler yöntemlerle parazitlenme oranı daha yüksek bulunmuştur (Franck ve ark. 2017). Ancak konukçu içerisinde parazitoid DNA'sının saptanması, fonksiyonel parazitlenmeyi garantilemediği gibi bazı böceklerde parazitoit yumurtasına karşı geliştirilen kapsüllenme reaksiyonu da göz ardı edilmemelidir.

Parazitoidlerin konukçu aralığının konvansiyonel metodlarla belirlenmesinin zor olduğu durumlar söz konusu olabilir. Özellikle yumurta parazitoitlerinde konukçunun teşhis edilmesi yumurta morfolojisine bağlıdır, hatta tanımlanabilir döneme kadar çoğunlukla konukçu parazitoit tarafından tüketilmiş olur. Benzer şekilde doğada başarılı parazitlenmenin hesaplanması da kolay olmayabilir. Özellikle Pentatomid yumurtalarının dağınık olması ve arazide çok sayıda yumurtanın bulunmaması bu duruma örnek verilebilir. Yumurta bulunsa bile konukçu ya da parazitoid hali hazırda yumurtayı terk etmiş ve geriye boş yumurta kümesi kalmış olabilir. Dolayısıyla ikili ilişkiye dair bilgi elde etmek imkânsız hale gelir. Bu amaçla yapılan bir çalışmada Pentatomidae ve Scelionidae familyalarına ait araziden toplanmış boş yumurta paketleri, parazitlenmiş ve parazitlenmemiş yumurtalar analiz edilmiştir. Geliştirilen DNA barkodlama yöntemi ile parazitlenmeden bir saat sonra bile yumurtaların parazitlenip parazitlenmediği, hangi parazitoitler tarafından parazitlendiği hatta hiperparazitoid türlerinin dahi tür düzeyinde tespitleri \%100 başarı ile yapılmıştır (Gariepy ve ark. 2014). Ülkemizde süne mücadelesinde yaygın olarak kullanılan yumurta parazitoitlerinden Trissolcus türlerinin ve yine kullanılma potansiyeli olan ergin parazitoitlerinin DNA barkodları gen bankasında kayıt altına alınarak sözü edilen amaçlarla kullanılmak üzere araştırıcıların hizmetine sunulmuştur (Guz ve ark. 2013; Duman ve ark. 2015).

Feromon tuzakları zararlıların izlenmesi ve mücadele zamanının belirlenmesi konusunda kuşkusuz kullanışlı araçlar olmasına rağmen bazı türler için spesifik olma konusunda yetersiz kalabilmektedir. Nitekim elma plantasyonlarında COI geninin barkodlanması ile Grapholita molesta'nın genetik varyasyonunun araştırıldığı çalışmada, hedef zararlı için geliştirilen feromon tuzaklarında beklenmedik bir şekilde yüksek oranda başka bir kriptik tür olan Grapholita funebrana bulunmuştur (Zheng ve ark. 2017).

Biyoçeşitliliğin önemli tehditlerinden olan istilacı türlerin hızlı ve doğru tanılanması biyogüvenlik açısından oldukça önemlidir. Yeni türlerin belirlenmesi ve mevcut zararlı türlerin izlenmesi açısından DNA barkodlama yaklaşımı kullanılarak yapılan tanılama çalışmaları diğer moleküler tekniklere kıyasla daha iyi çözümler sunmuştur (Armstrong ve Ball 2005). Florida'ya giriş yapan istilacı Spodoptera littoralis ile Spodoptera litura (Nagoshi ve ark. 2011); Hindistan ve Çin'de ilk defa saptanan Thrips parvispinus ve Echinothrips americanus (Tyagi ve ark. 2015; Wei ve ark. 2010) ve Brezilya'da Heliothis armigera ile Heliothis zea türlerinin birbirinden ayrılması (Mastrangelo ve ark. 2014), moleküler teknikler kullanılarak yapılan tür tanımlaması çalışmalarına verilebilecek güncel örneklerdir. DNA barkodlamanın tür tanılanmasındaki etkinliği göz önüne alınarak başlatılan Karantina Barkod Yaşam Projesi'nde [Quarantine Barcode of Life project (www.qbol.org)] bitki sağlığını desteklemek amacıyla karantina organizmalarının standart metotlarla tanılanması hedeflenmiştir.

Birbirine yakın türlerin hatta aynı türün farklı genotiplerinin insektisit direnci açısından farklılık göstermesi zararlı tür kompleksleriyle mücadeleye farklı bakış açısı kazandırmıştır (Van Toor ve ark. 2008). Bemicia tabaci kompleksinin iki kriptik türü olan Mediterranean ve Middle East-Asia Minor 1 (MEAM 1) popülasyonları insektisitlere hassasiyet açısından farklılık göstermiştir (Smith ve ark. 2016). Bu iki kriptik beyazsinek türü $C O I$ barkod dizisinden faydalanılarak geliştirilen primerler ile kolayca ayrılabildiği ortaya konmuştur (Shatters ve ark. 2009).

Lepidoptera, taksonomik ve sistematik olarak dikkat çeken ve çeşitlilik gösteren önemli bir böcek grubudur. Taksonomistlerin sayısının az olması ve türler arasında morfolojik benzerliğin yüksek olmasından dolayı çoğu 
Lepidopter türü hala tanılanmayı beklemektedir (Wilson 2003). Hebert ve ark. (2003a) yaptıkları çalışmada Kuzey Amerika' daki farklı kelebek türlerinin ayrılmasında COI geninin oldukça başarılı olduğunu vurgulamıştır. $\mathrm{Bu}$ çalışmadan sonra Lepidoptera takımı barkodlama çalışmaları için model bir grup olarak kayda geçmiştir. Bu ilerleme ile Lymantriidae familyasına ait pek çok türün ergin, yumurta ve larva dönemlerinin DNA barkodlama yöntemi ile tanımlandığı ortaya konmuştur (Ball ve Armstrong 2006). Astraptes fulgerator türünün DNA barkod analizinin yapıldığ bu çalışma, özellikle morfolojik ve ekolojik verilerin birleştirildiği zaman, tür keşfine nasıl yardımcı olabileceğini gösteren örnek bir çalışma olmuştur. Aynı çalışmada 484 numunenin barkodlanması ile A. fulgerator grubunun ergin ve larva morfolojilerine dayalı tanımlamadan ortaya çıkan şüpheler doğrulanmış ayrıca simpatrik türlerin varlığı da ortaya konulmuştur (Hebert ve ark. 2004). Hajibabaei ve ark. (2006) tarafından Lepidoptera faunasından üç farklı familyaya (Hesperiidae, Saturniidae ve Sphingidae) ait türlerin barkodlandığı çalışmada, 521 türün 4000 'den fazla bireyinin COI genine ait dizi analizleri yapılarak bireylerin $\% 97,9$ oranında tür ayrımı yapılmıştır.

Sinekler (Diptera), yaklaşık 150.000 türü teşhis edilmiş olan başka bir hiper-çeşitlilikteki böcek takımını oluşturur (Grimaldi ve Engel 2005; Beutel ve Pohl 2006). Yapılan araştırmalar standart COI geninin, Kanada ve Hindistan'daki sivrisineklerin tür düzeyinde tanılanmasına etkili bir şekilde hizmet ettiğini göstermiştir (Cywinska ve ark. 2006; Kumar ve ark. 2007). Başka bir çalışmada Smit ve ark. (2013) tarafından Avrupa'daki meyve sineklerinin yarısı barkodlanarak morfolojik karakterlere dayalı teşhisleri doğrulanmış ve Tephritid barkodlama veri tabanına önemli katkılar sağlamıştır.

DNA tabanlı tür tanımlama adli bilimciler tarafından da etkin bir şekilde kullanılmaktadır. Calliphoridae ve Sarcophagidae takımlarına bağlı et sinekleri cesetler üzerine ölümden kısa süre sonra yumurtalarını bırakır. Sadece ergin bireylerin güvenilir şekilde tanımlanabildiği bu türlerde, larvaları önceden toplamak ve yetiştirmek önemli bir zaman kaybına yol açmaktadır (Nelson ve ark. 2007). Bu zorluğun üstesinden gelmeye çalışan adli entomologlar DNA dizilerinin çoğunlukla COI bölgesinden faydalanarak adli öneme sahip bu sinek türlerinin doğru şekilde ayırt edebileceğini gösteren ayrıntılı çalışmalar yapmıştır (Sperling ve ark. 1994; Malgorn ve Coquoz 1999; Vincent ve Vian 2000; Wallman ve Donnellan 2001; Wells ve Sperling 2001; Wells ve ark. 2001).

Yaprak galeri sinekleri (Agromyzidae familyası), tür sınırlarını belirlemenin zor olduğu bir grubu oluşturmaktadır (Scheffer and Wiegmann 2000). Filipinler'de yaprak galeri sineklerinin üç türüne ait (Liriomyza huidobrensis, L. trifolii ve L. sativae) 258 bireyden COI sekansları elde edilerek tüm örnekler doğru morfolojilere yerleştirilmiştir (Scheffer ve ark. 2006). Hem L. trifolii hem de L. sativae gruplarındaki bazı mitokondriyal dizilerdeki farklılıklar yeni ve kriptik türleri önerecek düzeyde yüksek bulunmuştur. Bunun ötesinde, COI dizileri dışında hiçbir veri bu sonucu desteklememiştir.

Küresel biyoçeşitliğin önemli bileşenleri olan parazitoidler aynı zamanda konukçu türleri üzerinde de önemli etkilere sahiptir. Parazitoidler güçlü konukçu spesifitesi ile ayırt edilmesi nedeniyle morfolojik olarak kriptik türlerin büyük oranda çeşitliliğini gizlemektedir (Godfray 1994). Doğadan toplanan Lepidopter türlerinden çıkan Tachinid grubundan Belvosia cinsi parazitoit türlerinin morfolojik özellikleri kaydedilerek COI genine ait DNA dizileri çıkarılmıştır (Smith ve ark. 2006). Elde edilen DNA dizileri sadece kayıtlı olan Belvosia cinsine ait 17 türü ayırt etmekle kalmamış aynı zamanda 32 yeni kayıt türü literatüre kazandırarak bunlardan 3 türün konukçuya özelleşmiş kriptik tür olduğu bildirilmiştir. Sözü edilen çalışma DNA barkodlamanın morfolojik olarak teşhisi zor gruplarda bilinmeyen çeşitliliği ortaya çıkarma gücünü göstermiştir.

Coleoptera takımı, taksonomik olarak çeşitliliğin çok olduğu başka bir grubu temsil etmektedir. Kore Ulusal Bilim Müzesi'ndeki araştırıcılar 179 Coleopter örneğinin DNA barkodlarını çıkararak kayıt altına aldıkları bilgiyi konu uzmanı araştırıcıların hizmetine sunmuştur (Jung ve ark. 2016). 4286 adet Chrysomelid örneğinin incelendiği tez çalışmasında özellikle renk, büyüklük ve şekil bakımından varyasyon gösteren türlerin, kriptik türlerin ve morfolojik tanımlamada eksternal karakterlerin yetersiz olduğu türlerin ayrımında DNA barkodlama tekniğinin daha güvenilir sonuçlar verdiği ifade edilmiştir (Thorman ve ark. 2015).

Hymenoptera takımı yaklaşık 125.000 türü ile Coleoptera, Lepidoptera ve Diptera'dan sonra gelen dördüncü büyük böcek takımıdır (Grimaldi ve Engel 2005; Beutel ve Pohl 2006). Madagaskar'da bulunan karınca faunası, yaklaşık 1000 tür içerdiği tahmin edilen ve bunlardan \%96'sının endemik olduğu düşünülen hiper-çeşitlilik grubunu temsil etmektedir. Smith ve ark. (2005) tarafindan morfolojik tür tanımlamalarına alternatif olarak öne sürülen DNA barkodlama tekniği ile yapılan çalışmada, dört lokaliteden toplam 280 örnek toplanarak hem morfolojik karakterler kullanılmış hem de COI genine ait DNA dizileri çıkarılmıştır. Sonuçlar tek başına morfolojik yöntemlerle ayrılması zor veya imkânsız olan kriptik taksonların tespit edilmesinde kullanılan moleküler markörlerin başarısını ortaya koymuştur. 


\section{Sonuç}

DNA barkodlamanın bazı avantajları ve dezavantajları ortaya konuldukça moleküler, morfolojik ve ekolojik çalışmaları entegre eden taksonomik yaklaşımlarda maksimum verim sağlayacağı aşikardır (Dasmahapatra ve Mallet 2006). DNA dizi çalışmasından elde edilen kanıtlar, böyle bir sistemin fizibilitesini büyük ölçüde doğrular niteliktedir (Waugh 2007). Bu kapsamda DNA barkodlama yönteminin taksonomistler ve tür tanımlamasıyla ilgilenen uzmanların çalışmalarını hızlandıracağı kuşkusuzdur. Bazı kısıtlamalarına rağmen DNA barkodlamanın çalışılan örnekleri tür ve/veya daha alt seviyedeki taksonlarda ayırt etmede ve özellikle kriptik türlerin ortaya çıkmasında gösterdiği başarı dikkat çekicidir. Yakın gelecekte DNA barkodlamanın çeşitli organizmalar için standart bir tanımlama protokolü haline geleceği düşünülmektedir. Son olarak DNA barkodlamanın sadece taksonomik çalışmalarda değil entegre zararlı yönetimi programlarının ve karantina sistemlerinin vazgeçilmez bir aracı olacağına inanılmaktadır.

\section{Kaynaklar}

Ahrens D, Monaghan MT, Vogler AP (2007). DNA-based taxonomy for associating adults and larvae in multispecies assemblages of chafers (Coleoptera: Scarabaeidae). Mol Phylogenet Evol. 44: 436-449.

Alberts B, Johnson A, Lewis J, Raff R, Roberts K, Walter P (2002). The genetic systems of mitochondria and plastids. Molecular Biology of the Cell. 4th Edn. New York: Garland Science.

Amaral AR, Sequeira M, Coelho MM (2007). A first approach to the usefulness of cytochrome c oxidase I barcodes in the identification of closely related delphinid cetacean species. Mar Freshwater Res. 58: 505-510.

Armstrong K, Ball S (2005). DNA barcodes for biosecurity: Invasive species identification. Philos Trans R Soc Lond B Biol Sci. 360: 1813-1823.

Arnot DE, Roper C, Bayoumi RAL (1993). Digital codes from hypervariable tandemly repeated DNA sequences in the Plasmodium falciparum circumsporozoite gene can genetically barcode isolates. Mol Biochem Parasitol. 61: 15-24.

Asahida T, Yamashita Y, Kabayashi T (1997). Identification of consumed stone flounder Kareius bicoloratus (Basilewsky), from the stomach contents of sand shrimp, Crangon affinis (De Hann) using mitochondrial DNA analysis. J Exp Mar Bio Ecol. 217: 153-163.

Ball SL, Armstrong KF (2006). DNA barcodes for insect pest identification: a test case with tussock moths (Lepidoptera: Lymantriidae). Can J For Res. 36: 337-350.

Beutel RG, Pohl H (2006). Endopterygote systematics-where do we stand and what is the goal (Hexapoda, Arthropoda)? Syst Entomol. 31: 202-219.

Blaxter M (2003). Counting angels with DNA. Nature. 421: 22-124.

Blaxter ML (2004). The promise of a DNA taxonomy. Philos Trans R Soc Lond B Biol Sci. 359: 669-679.

Busse HJ, Denner EBM, Lubitz W (1996). Classification and identification of bacteria: current approaches to an old problem. Overview of methods used in bacterial systematics. J Biotech. 47: 3-38.

Cywinska A, Hunter FF, Hebert PDN (2006). Identifying Canadian mosquito species through DNA barcodes. Med Vet Entomol. 20: 413-424.

Çakmak I, Janssen A, Sabelis MW (2006). Intraguild interactions between the predatory mites Neoseiulus californicus and Phytoseiulus persimilis. Exp Appl Acarol. 38: 33-46.

Dasmahapatra KK, Mallet J (2006). Taxonomy: DNA barcodes: recent successes and future prospects. Heredity. 97: 254-255.

Duman M, Guz N, Sertkaya E (2015). DNA barcoding of sunn pest adult parasitoids using cytochrome c oxidase subunit I (COI). Biochem Syst Ecol. 59: 70-77.

Dunshea G (2009). DNA-based diet analysis for any predator. PLoS One. 4: e5252.

Farrell LE, Roman J, Sunquist ME (2000). Dietary separation of sympatric carnivores identified by molecular analysis of scats. Mol Ecol. 9: 1583-90.

Franck P, Maalouly-Matar M, Olivares J (2017). Molecular Tools for the Detection and the Identification of Hymenoptera Parasitoids in Tortricid Fruit Pests. Int J Mol Sci. 18 (10): 2031.

Foley DH, Wilkerson RC, Cooper RD, Volovsek ME, Bryan JH (2007). A molecular phylogeny of Anopheles annulipes (Diptera: Culicidae) sensu lato: the most species-rich anopheline complex. Mol Phylogenet Evol. 43: 283-297.

Folmer O, Black M, Hoeh W, Lutz R, Vrijenhoek R (1994). DNA primers for amplification of mitochondrial cytochrome c oxidase subunit I from diverse metazoan invertebrates. Mol Mar Biol Biotech. 3, 294299. 
Fournier V, Hagler J, Daane K, de Leon J, Groves R (2008). Identifying the predator complex of Homalodisca vitripennis (Hemiptera: Cicadellidae): A comparative study of the efficacy of an ELISA and PCR gut content assay. Oecologia 157: 629-40.

Funk DJ, Omland KE (2003). Species-level paraphyly and polyphyly: Frequency, causes, consequences, with insights from animal mitochondrial DNA. Annu Rev Ecol Syst. 34: 397-423.

Gariepy TD, Kuhlmann U, Gillott C, Erlandson M (2007). Parasitoids, predators and PCR: the use of diagnostic molecular markers in biological control of arthropods. J Appl Entomol. 131: 225-240.

Gariepy TD, Haye T, Zhang J (2014). A molecular diagnostic tool for the preliminary assessment of hostparasitoid associations in biological control programmes for a new invasive pest. Mol Ecol. 23: 39123924.

Gattolliat JL, Monaghan MT (2010). DNA-based association of adults and larvae in Baetidae (Ephemeroptera) with the description of a new genus Adnoptilum in Madagascar. J N Am Benthol Soc. 29: 1042-1057.

Godfray HCJ (1994). Parasitoids: Behavioral and Evolutionary Ecology. Princeton University Press, Princeton, New Jersey.

Gomez A, Wright PJ, Lunt DH, Cancino JM, Carvalho GR, Hughes RN (2007). Mating trials validate the use of DNA barcoding to reveal cryptic speciation of a marine bryozoan taxon. Proc R Soc Biol Sci Ser B. 274: 199-207.

Grimaldi DA, Engel MS (2005). Evolution of the Insects. Cambridge University Press, Cambridge.

Guz N, Kocak E, Kilincer N (2013). Molecular phylogeny of Trissolcus species (Hymenoptera: Scelionidae). Biochem Syst Ecol. 48: 85-91.

Hajibabaei M, Janzen DH, Burns JM, Hallwachs W, Hebert PDN (2006). DNA barcodes distinguish species of tropical Lepidoptera. Proc Natl Acad Sci USA 103: 968-971.

Hayashi M, Sota T (2010). Identification of elmid larvae (Coleoptera: Elmidae) from Sanin District of Honshu, Japan, based on mitochondrial DNA sequences. Entomol. Sci. 13: 417-424.

Hebert PDN, Cywinska A, Ball SL, deWaard JR (2003a). Biological identifications through DNA barcodes. Proc R Soc Lond B Biol Sci. 270: 313-321.

Hebert PDN, Ratnasingham S, deWaard JR (2003b). Barcoding animal life: cytochrome c oxidase subunit 1 divergences among closely related species. Proc Biol Sci. 270: 96-99.

Hebert PDN, Penton EH, Burns JM, Janzen DH, Hallwachs W (2004). Ten species in one: DNA barcoding reveals cryptic species in the neotropical skipper butterfly Astraptes fulgerator. Proc Natl Acad Sci USA. 101: 14812-14817.

Hogg ID, Hebert PDN (2004). Biological identification of springtails (Hexapoda: Collembola) from the Canadian Arctic, using mitochondrial DNA barcodes. Can J Zool. 82: 749-754.

Jung SW, Min HK, Kim Y, Choi HA, Lee SY, Baey J, Paek WK (2016). A DNA barcode library of the beetle refer- ence collection (Insecta: Coleoptera) in the National Science Museum, Korea. J. Asia Pac. Biodivers. 9: 234-244.

Jurado-Rivera JA, Vogler AP, Reid CAM, Petitpierre E, Gómez Zurita J (2009). DNA barcoding insecthostplant associations. Proc R Soc Lond B Biol Sci. 276: 639-648.

Kathirithamby J, Hayward A, Mcmahon DP, Ferreira RS, Andreazze R, Almeida Andrade HTD, Fresneau D (2010). Conspecifics of a heterotrophic heteronomous species of Strepsiptera (Insecta) are matched by molecular characterization. Syst Entomol. 35 234-242 .

Kehlmaier C, Assmann T (2010). Molecular analysis meets morphology-based systematics-a synthetic approach for Chalarinae (Insecta: Diptera: Pipunculidae). Syst Entomol. 35, 181-195.

King RA, Vaughan IP, Bell JR, Bohan DA, Symondson WOC (2010). Prey choice by carabid beetles feeding on an earthworm community analysed using species and lineagespecific PCR primers. Mol Ecol. 19: 172132.

Kohn MH, Wayne RK (1997). Facts from feces revisited. Trends Ecol Evol. 12, 223-227.

Kumar NP, Rajavel AR, Natarajan R, Jambulingam P (2007). DNA barcodes can distinguish species of Indian mosquitoes (Diptera: Culicidae). J Med Entomol. 44: 1-7.

Magnacca KN, Brown MJF (2010). Mitochondrial heteroplasmy and DNA barcoding in Hawaiian Hylaeus bees (Hymenoptera: Colletidae). BMC Evol Biol. 10, 174.

Malgorn Y, Coquoz R (1999). DNA typing for identification of some species of Calliphoridae. An interest in forensic entomology. Forensic Sci Int. 102: 111-119.

Mastrangelo T, Paulo DF, Bergamo LW, Morais EGF, Silva M, Bezerra-Silva G, Azeredo-Espin AM (2014). Detection and genetic diversity of a Heliothine invader (Lepidoptera: Noctuidae) from north and northeast of Brazil. J Econ Entomol. 107(3): 970-980.

Matheson CD, Muller GC, Junnila A, Vernon K, Hausmann A, Miller MA, Greenblatt C, Schlein Y (2007). A PCR method for detection of plant meals from the guts of insects. Org Divers Evol. 7, 294-303.

Meyer CP, Paulay G (2005). DNA barcoding: error rates based on comprehensive sampling. PLoS Biol. 3, e422. 
Miller KB, Alarie Y, Wolfe GW, Whiting MF (2005). Association of insect life stages using DNA sequences: the larvae of Philodytes umbrinus (Motschulsky) (Coleoptera: Dytiscidae). Syst Entomol. 30 499-509.

Monaghan MT, Balke M, Gregory TR, Vogler AP (2005). DNA-based species delineation in tropical beetles using mitochondrial and nuclear markers. Philos Trans R Soc Lond B Biol Sci. 360: 1925-1933.

Monaghan MT, Balke M, Pons J, Vogler AP (2006). Beyond barcodes: complex DNA taxonomy of a South Pacific Island radiation. Proc R Soc Lond B Biol Sci. 273: 887-893.

Moulton MJ, Song H, Whiting MF (2010). Assessing the effects of primer specificity on eliminating Numt coamplification in DNA barcoding: A case study from Orthoptera (Anthropoda: Insecta). Mol Eco Res. 10: $615-27$.

Murría C, Zamora-Muñoz C, Bonada N, Ribera C, Prat N (2010). Genetic and morphological approaches to the problematic presence of three Hydropsyche species of the pellucidula group (Trichoptera: Hydropsychidae) in the westernmost Mediterranean Basin. Aquat. Insects. 32: 85-98.

Nagoshi RN, Brambila J, Meagher RL (2011). Use of DNA barcodes to identify invasive armyworm Spodoptera species in Florida. J. Insect Sci. 11: 154.

Nelson LA, Wallman JF, Dowton M (2007). Using COI barcodes to identify forensically and medically important blowflies. Med Vet Entomol. 21: 44-52.

Page RD (2016). DNA barcoding and taxonomy: dark taxa and dark texts. Phil Trans R Soc B. $371: 20150334$.

Shatters Jr RG, Powell CA, Boykin LM, Sheng HL, McKenzie CL (2009). Improved DNA barcoding method for Bemisia tabaci and related Aleyrodidae: development of universal and Bemisia tabaci biotypespecific mitochondrial cytochrome c oxidase I polymerase chain reaction primers. J Econ Entomol. 102: $750-758$.

Nakahara S, Zacca T, Huertas B, Neild A, Hall J, Lamas G, Holian L, Espeland M, Willmott KR (2017). Remarkable sexual dimorphism, rarity and cryptic species: a revision of the 'aegrota species group' of the Neotropical butterfly genus Caeruleuptychia Forster, 1964 with the description of three new species (Lepidoptera, Nymphalidae, Satyrinae). Insect Syst Evol. 27 July 2017.

Smit J, Reijnen B, Stokvis F (2013). Half of the European fruit fly species barcoded (Diptera, Tephritidae); a feasibility test for molecular identification. ZooKeys. 365: 279-305.

Smith MA, Wood DM, Janzen DH, Hallwachs W, Hebert PDN (2007). DNA barcodes affirm that 16 species of apparently generalist tropical parasitoid flies (Diptera: Tachinidae) are not all generalists. Proc Natl Acad Sci USA. 104: 4967-4972.

Smith HA, Nagle CA, MacVean CA, McKenzie CL (2016). Susceptibility of Bemisia tabaci MEAM1 (Hemiptera: Aleyrodidae) to imidacloprid, thiamethoxam, dinotefuran and flupyradifurone in south Florida. Insects. 7: 57.

Thorman B (2015). Biodiversity of leaf beetles (Coleoptera: Chrysomelidae) in a tropical montane rainforest ecosystem assessed with DNA barcoding. PhD thesis. University of Bonn. 250 pages.

Pauls SU, Blahnik RJ, Zhou X, Wardwell CT, Holzenthal RW (2010). DNA barcode data confirm new species and reveal cryptic diversity in Chilean Smicridea (Smicridea) (Trichoptera: Hydropsychidae). J N Am Benthol Soc. 29: 1058-1074.

Pfenninger M, Nowak C, Kley C, Steinke D, Streit B (2007). Utility of DNA taxonomy and barcoding for the inference of larval community structure inmorphologically cryptic Chironomus (Diptera) species. Mol Ecol. 16: 1957-1968.

Pons J (2006). DNA-based identification of preys from nondestructive, total DNAextractions of predators using arthropod universal primers. Mol Ecol Notes. 6: 623-626.

Rach J, Bergmann T, Paknia O, DeSalle R, Schierwater B, Hadrys H (2017). The marker choice: Unexpected resolving power of an unexplored CO1 region for layered DNA barcoding approaches. PLoS One, 12(4), e0174842.

Sanger F, Nicklen S, Coulson AR (1977). DNA sequencing with chain-terminating inhibitors. Proc Natl Acad Sci USA. 74: 5463-5467.

Scheffer SJ, Lewis ML, Joshi RC (2006). DNA barcoding applied to invasive leafminers (Diptera: Agromyzidae) in the Philippines. Ann Entomol Soc Am. 99: 204-210.

Scheffer SJ, Wiegmann BM (2000). Molecular phylogenetics of the holly leafminers (Diptera: Agromyzidae: Phytomyza): species limits, speciation, and dietary specialization. Mol Phylogenet Evol. 17: 244-255.

Schindel DE, Miller SE (2005). DNA barcoding a useful tool for taxonomists. Nature. 435: 17.

Sheppard SK, Harwood JD (2005). Advances in molecular ecology: tracking trophic links through predator-prey foodwebs. Funct Ecol. 19: 751-762.

Smith MA, Woodley NE, Janzen DH, Hallwachs W, Hebert PDN (2006). DNA barcodes reveal cryptic hostspecificity within the presumed polyphagous members of a genus of parasitoid flies (Diptera: Tachinidae). Proc Natl Acad Sci USA. 103: 3657-3662. 
Smith MA, Fisher BL, Hebert PDN (2005). DNA barcoding for effective biodiversity assessment of a hyperdiverse arthropod group: the ants of Madagascar. Philos Trans R Soc Lond B Biol Sci. 360: 1825 1834.

Sohrabi F, Annie E, Parviz S, Moosa S, Mohammad SM (2013). Intraguild predation by the generalist predator Orius majusculus on the parasitoid Encarsia formosa. Biol Control. 58: 65-72.

Sperling FA, Anderson GS, Hickey DA (1994). A DNA-based approach to the identification of insect species used for postmortem interval estimation. J Forensic Sci. 39: 418-427.

Sutou M, Kato T, Ito M (2007). Description of the final larval stage and the pupa of Ctenosciara japonica (Diptera: Sciaridae) and their DNA barcodes. Studia Dipt. 14: 17-22.

Thomas A, Trotman J, Wheatley A, Aebi A, Zindel R, Brown PMJ (2013). Predation of native coccinellids by the invasive alien Harmonia axyridis (Coleoptera: Coccinellidae): detection in Britain by PCR based gut analysis. Insect Conserv Divers. 6: 20-27.

Thomsen PF, Elias S, Gilbert MTP, Haile J, Munch K, Kuzmina S, Froese DG, Sher A, Holdaway RN, Willerslev E (2009). Non-destructive sampling of ancient insect DNA. PLoS One. 4: e5048.

Tyagi K, Kumar V, Singha D, Chakraborty R (2015). Morphological and DNA barcoding evidence for invasive pest thrips, Thrips parvispinus (Thripidae: Thysanoptera), newly recorded from India. J Insect Sci. 15 (105).

Van Houdt JKJ, Breman FC, Virgilio M, de Meyer M (2010). Recovering full DNA barcodes from natural history collections of Tephritid fruitflies (Tephritidae, Diptera) using mini barcodes. Mol Ecol Resour. 10, 459465.

Van Toor RF, Foster SP, Anstead JA, Mitchinson S, Fenton B, Kasprowicz L (2008). Insecticide resistance and genetic composition of Myzus persicae (Hemiptera: Aphididae) on field potatoes in New Zealand. Crop Prot. 27 (2): 236-247.

Vincent SJ, Vian M Carlotti MP (2000). Partial sequencing of the cytochrome oxydase b subunit gene I: a tool for the identification of European species of blow flies for postmortem interval estimation. J Forensic Sci. 45: 820-823.

Virgilio M, Backeljau T, Nevado B, De Meyer M (2010). Comparative performances of DNA barcoding across insect orders. BMC Bioinformatics 11: 1-10.

Wallman JF, Donnellan SC (2001). The utility of mitochondrial DNA sequences for the identification of forensically important blowflies (Diptera: Calliphoridae) in southeastern Australia. Forensic Sci Int 120 (1-2): 60-67.

Waugh J (2007). DNA barcoding in animal species: progress, potential and pitfalls. Bioessays. 29: 188-197.

Weber DC, Lundgren JG (2009). Detection of predation using qPCR: Effect of prey quantity, elapsed time, chaser diet, and sample preservation on detectable quantity of prey DNA. J Insect Sci. 9: 1-12.

Wei SJ, Mirab-Balou M, Shi BC, Gong YJ, Liu J, Kang ZJ, Xue-Xin C, Hong L (2010). External morphology and molecular identification of the newly found invasive pest Echinothrips americanus Morgan (Thysanoptera: Thripidae) in China. Acta Entomol. Sin. 53 (6): 715-715.

Wells JD, Sperling FA (2001). DNA-based identification of forensically important Chrysomyinae (Diptera: Calliphoridae). Forensic Sci Int 120: 110-115.

Wells JD, Pape T, Sperling FA (2001). DNA-based identification and molecular systematics of forensically important Sarcophagidae (Diptera). J Forensic Sci 46: 1098-1102.

Wilson EO (2003). The encyclopedia of life. Trends Ecol. Evol. 18: 77-80.

Zaidi RH, Jaal Z, Hawkes NJ, Hemingway J, Symondson WOC (1999). Can the detection of prey DNA amongst the gut contents of invertebrate predators provide a new technique for quantifying predation in the field? Mol Ecol 8: 2081-2088.

Zheng Y, Wu R, Dorn S, Chen M (2017). Diversity of tortricid moths in apple orchards: Evidence for a cryptic species of Grapholita (Lepidoptera: Tortricidae) from China. Bull Entomol Res 107 (2): 268-280. 